known as 'revolutionary methods'. He illustrates this progress by what is happening in the coal-mining industry. The hewing of coal by pick and filling it into a tub by shovel, in a more or less confined space, is work of the most arduous nature. The great expansion during recent years of mechanical coal cutters has made this work comparatively easy. In 1900 only 1.5 per cent of the British coal output and 25 per cent of the output of the United States was cut mechanically. In 1932 this had risen to 38 per cent in Britain and 68 per cent in the United States. In the Ruhr coalfield the mechanical pick has found great favour; in 1913 only $2 \cdot 2$ per cent was cut mechanically, now 90 per cent is, 84 per cent being cut by mechanical picks and 6 per cent by mechanical coal cutters. The transport of the cut coal from the coal face to the shaft bottom was almost as laborious as 'getting' the coal. Now, owing to the perfection of electrically actuated plant, not only is the haulage on the main roads carried out electrically, but in the secondary roads also it is replacing horses and ponies. So far as creation of wealth and increase of leisure and comfort of the mass of mankind are concerned, the engineer has taken a leading part. During the last 130 years, wages in coal-mining have risen $3 \cdot 2$ times and the daily time of labour has been decreased 37 per cent, the return on the capital remaining on the average stationary. The chief beneficiary under the system of mechanisation has been the manual worker. There is no doubt that the rationalisation of industry tends to decrease the number of employees, but Sir Richard Redmayne thinks that the lowering of the price of the commodity, its more effective distribution leading to the increase of new industries, together with the increase in wages and leisure creating an increased demand, will result in more than the absorption of the overplus of labour.

\section{Unemployment among Young Persons}

THE International Labour Office estimates that of about 25 million unemployed throughout the world, about one fourth, or 6-7 million, are young persons less than twenty-five years of age. In Great Britain the percentage between fourteen and twenty-four years old was 30.2 per cent in 1931, a figure which indicates the significance of the National Jubilee Trust inaugurated by the Prince of Wales. The corresponding figure for Switzerland in July 1934 was 15 per cent, but for Hungary in 1930 it reached 42 per cent ; in Italy in $1932,41.5$ per cent of the unemployed were between fifteen and twenty-five years of age. These figures indicate the quantitative significance of the discussions on unemployment among young persons at the International Labour Conference opening at Geneva on June 4. They do not, however, reveal the demoralising effects of prolonged unem. ployment, which are much more serious among young than among older persons. Steps already taken by various countries to deal with this position are indicated in a report prepared by the International Labour Office as a basis for the discussions. The report suggests that most of the measures to be taken to ameliorate unemployment among young persons call for pooling of experience rather than for the drafting of a convention. Particular stress is laid upon the raising of the school-leaving age to fifteen years; the creation of an increased number of technical schools; the organisation of vocational training centres in connexion with public employment agencies and the establishment of centres for recreation, physical training, etc.

\section{Molecular Structure of Dielectrics}

SrR Wilutam BragG chose the molecular structure of dielectrics as the subject of the twenty-sixth Kelvin Lecture delivered on May 2 to the Institution of Electrical Engineers. He pointed out that the properties of dielectrics depend on their composition and on the arrangement of their atoms and molecules. During the past twenty-five years, men of science have used $\mathrm{X}$-rays to study the structure of various substances, and engineers by other means have discovered many of the factors which govern the properties of dielectrics. It is now necessary that the two classes of workers should come together and pool their resources in making further advances. It is sometimes thought that $\mathrm{X}$-rays are only of use for examining the structure of crystals, but it has to be remembered that crystallisation is a property of all substances. The crystal is used to obtain electron maps of the image of a single molecule and these maps enable us to find out the electron densities in its various parts. It is possible in many molecules to measure the exact distance from atom to atom, and to determine the way in which they are linked together to form the molecules. This method of attack can be used even when the molecules are not so definite in shape as they are in a crystal. Sir William pointed out the analogies between the properties of proteins and those of dielectrics and laid stress on the recent work done at Leeds by Mr. W. T. Astbury. Once the basic theory of dielectrics is determined, rapid progress will be made in practical applications. It is fortunate that the researches in the pure science of atoms and molecules and the many technical investigations now being carried on are feeling their way towards each other.

\section{The New Commonwealth Society}

Accordrra to the annual report of the New Commonwealth for 1933-34, a clearer demarcation will in future be drawn between the research and propaganda activities of this organisation. Educa. tional and propaganda work will be undertaken by the New Commonwealth Society, which will continue to be subdivided into an international section and the various national sections. Brief reports of the activities of all these sections are included, which indicate the extent to which the scientific study of international affairs is being encouraged in this way. The scientific investigations hitherto carried out by the Research Bureau of the International Section will now be carried out by the New Commonwealth Institute. These activities are guided by an Advisory Research Committee, which includes among its 
members Major-Gen. Sir F. Maurice, Brig.-Gen. E. L. Spears, Prof. A. Zimmern, Prof. N. J. Baker, Prof. H. V. Temperley, President N. B. Butler, M. Nicolas Politis. This Committee will advise upon research work on the principles of international relations, questions of international justice, law and equity, and problems of international security. The publications of the Institute will include monographs and a quarterly review in English, German and French, and preparations are being made for the publication of a yearbook. The work is largely carried out by means of circular letters, but it is also proposed to hold conferences twice a year in different centres. A series of fortnightly 'round table' discussions has also been initiated.

\section{Training for Industrial Management}

IN a report entitled 'Three Years' Experience and Results in the Training of Scientific Men for Industrial Management" (57 Gordon Square, London, W.C.1), Mr. W. R. Dunlop describes the work which he has carried out in providing facilities for training in this subject on the lines of personal and individual tuition, and more recently by correspondence. The courses, he explains, were not undertaken in the expectation of obtaining spectacular results; but experience has shown that scientific and technical men are definitely interested, and that those who have taken full advantage of the training have derived substantial benefit in one way or another. A difficulty has been to get something out of the students as well as putting something in. It has been hard to make chemists in particular understand that management is not a subject but an activity, and that action, energy and initiative as well as passive absorption of knowledge must be demonstrated in a course of training. Chemists in some cases appear to suffer from an 'inferiority complex' in regard to expressing opinions on matters outside their immediate province, while on the other hand many engineers, especially mechanical engineers, tend to go to the other extreme.

\section{Public Health in British Colonies in 1932}

THE fourth Supplement to the Tropical Diseases Bulletin, December, 1934, contains summaries by Dr. Harold Scott of medical and sanitary reports relating to the year 1932 from British colonies, protectorates, and dependencies. The summaries give for each country the year's record of vital statistics, maternity and child welfare work, school hygiene, general sanitation, housing and town planning, etc., followed by particulars of the tropical diseases occurring in them, and the measures taken locally to combat them. The records show, on the whole, that in spite of retrenchments of medical staffs and curtailment of expenditure on public health services, the general health of the English communities has been well maintained, and no appreciable increase of sickness has occurred in the native communities. Retrenchment has had the effect of bringing to the fore the question of the local training of natives for medical duties. In the Gold Coast, a scheme for the training of nurse-dispensers has been instituted, and elsewhere medical schools exist where native prac. titioners have been successfully trained.

\section{Ross Institute Industrial Advisory Committee}

A meeting of this Committee, at which the chairman, Mr. G. H. Masefield, presided, was held on January 29 last at the rooms of the Indian Tea Association. The meeting was addressed by Sir Malcolm Watson, who described some of the antimalarial measures that have been undertaken in Southern Rhodesia, Beira and some of the Gold Coast mines, by Mr. A. Wigglesworth, who raised the question of malarial conditions on sisal estates, and by others. Dr. Ramsay, of the Ross Institute in India, mentioned the 'eye fly', which is not only a nuisance but also a danger, as it transmits catarrhal conjunctivitis, and against which no effective measures are known except protection by means of wire gauze spectacles. Sir Malcolm Watson directed attention to a booklet on the prevention of malaria which is distributed free to those residing in, or proceeding to, the tropics. The Ross Institute, which is amalgamated with the London School of Hygiene and Tropical Medicine, is the medium through which industries in the tropics keep in touch with the work of the combined bodies and seek advice, and some $£ 15,000$ are required annually from voluntary subscriptions for propaganda work and appeals.

\section{Microscopes and Accessory Apparatus}

IN the 1934 edition of the catalogue issued by Messrs. Carl Zeiss (London), Ltd. (37 Mortimer Street, London, W.1), after an excellent introduction upon the theory of the microscope, the series of microscope stands manufactured is described. The design of the microscope stand has substantially altered in recent years, and the usual form now adopted consists of a broad base which supports a one-piece limb for carrying the illuminating system, the stage and the tube. This one-piece limb is in the form of a segment of a circle with a deep central recess. This recess serves as a handle, and provides ample range for a large stage. Another convenient modern device is the inclined tube, single or binocular, which can be fitted to most of the models, in some of which the fine-adjustment head is located in the tilting axis. A large range of Huygenian and compensating eyepieces, and achromatic, fluorite and apochromatic objectives, are manufactured. Petrological and other types of special stands, magnifiers, hæmacytometers, micrometers, micro-manipulator, photomicrographic cameras and other accessory apparatus are also listed.

\section{Research on Bird Migration}

THE German Government has issued an announcement referring to the work of the German bird migration research stations-in Heligoland and at Rossitten-where rings are attached every year to the feet of more than 160,000 migratory birds. The rings are inscribed with identification numbers and with the address of one or other of the stations"Vogelwarte Helgoland" or "Vogelwarte Rossitten" 